\title{
Gauguin: Lima como un paraíso perdido
}

\author{
Fernando de Szyszlo \\ Academia Peruana de la Lengua
}

\begin{abstract}
Tengo una remarcable memoria visual y recuerdo nuestra casa de esa época y tantas cosas... el Palacio de la Presidencia, la iglesia cuya cúpula había sido colocada posteriormente y que era esculpida en madera. Veo todavía a nuestra pequeña negrita, la que debía, según la regla, llevar la pequeña alfombra sobre la que arrodillábamos para rezar. Neo también nuestro doméstico chino que sabía tan bien planchar la ropa. Fue él, por otra parte, el que me encontró en una tienda de abarrotes en donde estaba comiendo una caña de azúcar entre dos barriles de melaza, mientras que mi madre desesperada me hacía buscar por todas partes... En su calidad de muy ñoblècespaneladmi madre ara violenta y yo recibí algunas bofetadas destepéquênia manosuave como de caucho... En Lima, en donde jamás llueve, el tejado es una terraza en donde se encuentran locos atados por un anillo a una cadena y que el propietario debe alimentar. Recuerdo que un día mi hermana, la pequeña negrita y yo estábamos acostados en mi cuarto, cuya puerta daba a un patio interior, y fuimos despertados al percibir al loco que descendía la escalera. La luna iluminaba el patio. Ninguno de nosotros se atrevió a decir palabra. Vi, y veo todavía, al loco entrar en nuestro cuarto, contemplarnos, y luego tranquilamente volver a subir la terraza.
\end{abstract}

De esta manera recordaba Paul Gauguin su estadía en Lima, en su libro Avant et Après, escrito en 1903, el año de su muerte, 54 años después de su llegada al Perú. La casa de don Pío Tristán, en donde estaba alojado, ahora 
es el número 234 de la avenida Emancipación. Allí vivieron los Gauguin desde agosto de 1849 hasta agosto de 1854 , mejor dicho desde que Paul tenía un año hasta los seis años de edad. Era, pues, un niño, y por ello es más impresionante comprobar que esos años lo marcaron de una manera indeleble más aún, inclinaron su vida hacia la búsqueda de un paraíso perdido en ese país irrecuperable que es la infancia. Esa edad de oro la persiguió toda su existencia y lo llevó, primero, adolescente, como marino mercante y luego en la armada francesa a todos los océanos del mundo. Más tarde, ya descubierta su vocación de pintor, lo hizo ir a Martinica, Panamá y finalmente a Tahití y las Islas Marquesas.

Quizás sea útil hacer un poco de historia. La abuela de Paul Gauguin era Flora Tristán. Personaje fascinante que dejara un recuerdo permanente en la historia del socialismo en Francia. Flora Tristán es hija de don Mariano Tristán Moscoso, por tanto sobrina del hermano de éste, Pío Tristán, virrey interino en los últimos momentos de la Colonia, y acaudalado residente de Arequipa y Lima.

La madre de Flora Tristán, Teresa Laisnay, escribe repetidamente a don Pío Tristán reclamándole la parte de la herencia que le corresponde. Nunca recibió respuesta. Será Flora la que consiga que su tío entre en contacto con ella. Después de un matrimonio fracasado con un pintor grabador de nombre André Chazal, del que tiene una hija, Alina -futura madre de Gauguin-, Flora, fatigada de la pobrezay mediocridad en que vive yatizada por los sueños de aristocracia y fortuna đque teehâlincuilcadò swomálę̧e decide a venir al Perú a recoger su herencia. Es quizá el fracaso de este intento de recuperar lo que considera suyo y que le es escamoteado, lo que radicaliza su manera de pensar y la inclina totalmente hacia la política. Antes escribirá un libro importante: Peregrinaciones de una paria, publicado en 1836, dos años después de su regreso al Perú, que le vale una cierta celebridad y la reputación de ser una pensadora socialista de vanguardia. En 1848, dos años después de su muerte, los obreros de Marsella le erigirán un monumento.

\section{TRAVESÍA AL PERÚ}

A la muerte de Flora Tristán es George Sand la que protege a Aline, que entonces tiene 19 años. En esta época Aline conoce a un periodista, Clovis Gauguin, cuya carrera está llena de promesas y, con la protección de George 
Sand, inicia Aline una relación que termina en matrimonio. Fruto de este matrimonio es una niña, Marie, nacida en 1847, y al año siguiente Paul, nacido el 7 de junio de 1848. Los avatares de la política francesa, en esos años tormentosos de la masacre de la Comuna y la ascensión al poder de Luis Napoleón, dejan sin trabajo a un periodista de ideas republicanas como era Clovis Gauguin. La crisis les devuelve a la memoria sus contactos con el Perú y con la familia Tristán Moscoso. ¿Por qué no ir en busca de una herencia que seguramente los está esperando?

Parten al Perú el 8 de agosto de 1849 Clovis Gauguin, su mujer Aline y sus hijos Marie, de dos años y medio, y Paul, de un año y dos meses. La travesía será larga y difícil. Al pasar el estrecho de Magallanes, Clovis sufre un ataque cardiaco y muere.

Es enterrrado en Port Famine, el sitio más extremo de la Patagonia. Tres meses después de haber salido de Francia, arriban al Callao. Los recién llegados son recibidos con los brazos abiertos y alojados espléndidamente en la enorme casa que tiene tres patios sucesivos. Esos años, en que todo está a su disposición y en que es atendido y cuidado como un niño privilegiado, quedarán grabados en la memoria de Gauguin.

De regreso a Francia en đonde su madre espera recibir la herencia de un tío, Guillaumin Gauguin, Paul es enviado a un colegio jesuita cerca de la

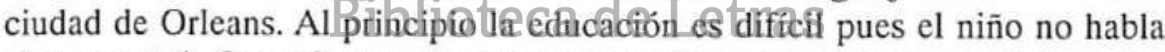
sino español. Gauguin conseryará tỏda lsü Yidavurasatractivo especial por las personas de esa lengua. No se sabe en donde vio por primera vez objetos de arte peruano precolombino, seguramente fue en 1871 en la casa de su protector Gustave Arosa. Los que pudo haber visto durante su estadía en Lima pueden haber quedado como muy vagos recuerdos, casi subconcientes. Pero todos los críticos especialistas en Gauguin están de acuerdo en encontrar a lo largo de su obra testimonios visuales de su interés por el arte precolombino.

En ninguna de las diferentes técnicas y medios que usó Gauguin para expresarse en esto más patente que en la cerámica. Muchas obras de cerámica de Gauguin tiene una influencia notoria de las cabezas mochica. Más tarde aparecen figuras vinculadas a las formas de las momias precolombinas. También en sus escritos y en sus expresiones orales se manifiesta el vínculo profundo que sentía dentro de él con el país donde había transcurrido su primera infancia. 
A menudo decía "soy dos cosas que no pueden ser nunca ridículas: un niño y un salvaje", otras veces gritaba: "Yo soy un salvaje del Perú", otra vez desde Bretaña le escribe a su amigo Schuffnecker: "el último [cuadro] es una lucha de dos chicos al borde del río, pintados por un salvaje del Perú".

Cuando termina su enrolamiento en la marina mercante francesa $y$, posteriormente, su servicio militar en la marina de guerra, su madre consigue que vaya a trabajar en una agencia de bolsa (Berlín) recomendado por los hermanos Arosa, financistas exitosos, de los que era una amiga cercana. Gustave Arosa se convierte en el tutor de Gauguin. Los Arosa deben su fortuna al comercio de guano del Perú que iniciara su padre.

La misteriosa relación con el Perú continúa: Gustave Arosa es coleccionista de objetos de arte precolombino, de platería colonial y muy especialmente de pintura. La parte precolombina de la colección Arosa es suficientemente importante para que en 1875 Demmin, que publica su segundo volumen de la Historia de la cerámica, reproduzca en gran formato piezas de la colección de Arosa y algunas de la colección de la madre de Gauguin, lo que nos provee la única ocasión de ver las piezas de arte precolombino con las que Gauguin vivió y que marcaron el desarrollo de sus búsquedas de una manera importante.

En la Exposición Universalede París đe 1878 podrá Gauguin ver otra colección, aún más grande, de arte precolombino, constituida por cerámica peruana, principalmente de las culturas mochica y chimú.

Es frente a la colección de Arosa que Gauguin descubre la pintura y su vocación. Viene entonces la guerra con Alemania en 1870, el sitio de París, la derrota. La casa de su madre en Saint-Cloud es incendiada por los prusianos. "Si creemos a Gauguin, todo lo que él había admirado y amado ha desaparecido, en particular los recuerdos de su infancia en el Perú: las cerámicas Inca han quedado pulverizadas, los amuletos en plata se han fundido y los papeles de la familia se han quemado", dice el crítico inglés David Sweetman. 